\title{
Role of IgG fractions with high isoelectric points in the thymol turbidity test in syphilis Evidence for an increase in basic IgG in early syphilis
}

\author{
J. J. VAN DER SLUIS AND H. E. MENKE
}

\author{
From the Research Laboratory, Department of Dermatology and Venereology, Erasmus University, \\ Rotterdam, The Netherlands
}

The thymol turbidity test (TTT) is a non-specific reaction, which gives results above normal in a variety of diseases (Stillerman, 1948). Chronic infection, for instance syphilis, is one of the conditions associated with increased thymol turbidity (TT) of serum (Weiss, 1969; Menke, 1975).

Factors contributing to the TT are discussed by Reinhold (1960). The free lipids of serum play a part, but proteins have also been found to react with the thymol reagent (Kunkel and Hoagland, 1947; Franklin, 1959).

Electrophoresis shows that the proteins precipitated by the thymol reagent behave like the beta and gamma proteins. The addition of gamma globulins to normal serum is followed by an increase in TT, and the removal of these proteins from positive TTT sera is followed by a negative reaction (Kunkel and Hoagland, 1947).

As Franklin (1959) has shown, basic fractions of the gamma region are important in the reaction. Although negative when tested alone, these fractions affect the TT when tested in the presence of lipoproteins. Hartmann, Viallet, and Fauvert (1963) described the so-called 'starter mechanism' of IgM. The addition of IgM myeloma proteins to normal serum was followed by an increase in TT, an effect which was not observed with IgG. However, when both IgM and IgG were added, the increase was larger than could be expected from the amount of IgM alone. These results indicate that some of the immunoglobulins play a part in the TTT. Since we were interested in the course of immunological events taking place after infection with $T$. pallidum, we investigated some of the factors contributing to the increased thymol turbidity in syphilis. In the experiments described in this communication, we studied the action of IgG isolated from syphilitic sera in the TTT.

\section{Material and methods}

All the chemicals used were of analytical reagent grade. Antisera were obtained from the Central Laboratory of the Dutch Red Cross (Amsterdam, The Netherlands) and

Received for publication August 30, 1974
Nordic (Tilburg, The Netherlands). Sera from syphilitic subjects were used either at once or after storage at $-70^{\circ} \mathrm{C}$. for varying lengths of time. In all cases the diagnosis was confirmed by a positive darkfield examination and/or a positive Treponema pallidum immobilization (TPI) reaction. The TTT was performed by diluting $0.1 \mathrm{ml}$. of serum with $6 \mathrm{ml}$. of thymol reagent $\mathrm{pH}=7.55$ to 7.60 (Baker, Deventer, The Netherlands).

After $30 \mathrm{~min}$. the turbidity was read on a Vitatron spectrophotometer at $637 \mathrm{~nm}$. Protein content was measured by the biuret reaction, using Lab-Trol (Dade, Miami, Florida, USA) as a standard.

Zone electrophoresis in Pevikon blocks was performed according to the method of Bocci (1964) in barbitalbarbital sodium buffer, $\mathrm{pH}=8.6, \mu=0.05$, in blocks measuring $36 \times 16 \times 1 \mathrm{~cm}$. 7 to $8 \mathrm{ml}$. serum from a syphilitic patient was dialysed in barbiturate buffer and applied to the block in a groove $12 \mathrm{~cm}$. from the cathodal end. A voltage gradient of $3.3 \mathrm{~V} / \mathrm{cm}$. was applied to the block.

After passage of current for $28 \mathrm{hrs,} \mathrm{the} \mathrm{block} \mathrm{was}$ divided into strips $1 \mathrm{~cm}$. wide. These strips were eluted in small columns with two volumes of $10 \mathrm{ml}$. saline. The amount of protein in the eluate was determined in order to judge the separation pattern. Fractions of the gamma region, usually eight, were concentrated by vacuum dialysis in $8 / 32$ Visking dialysing tubes. The protein content of the concentrated fractions was measured. These fractions were then tested by the TTT.

IgG was isolated from individual or pooled sera of syphilitic subjects, by a batch absorption method on DEAE Sephadex A 50 in $0.01 \mathrm{M}$ phosphate buffer, $\mathrm{pH}=6.7$ (Steffen, 1968). In pooling the sera no special attention was paid either to the stage of the disease or to that of current treatment. Purity was controlled by the microimmunoelectrophoresis method of Scheidegger (1955) and the double diffusion method of Ouchterlony (1958). Isoelectrofocusing of IgG was performed according to a slightly modified preparative method of Radola (1969) in layers of Sephadex G 75 Superfine of $0.23 \mathrm{~cm}$. thickness on glass plates, measuring $40 \times 16 \mathrm{~cm}$. In each run, approximately $250 \mathrm{mg}$. of IgG isolated from pooled syphilitic sera were separated, using 1 per cent. ampholines solution (LKB, Stockholm, Sweden), composed of equal parts of ampholines of $\mathrm{pH}$ range 5-8 and 8-10 in distilled water. Upon the completion of the run, usually $48 \mathrm{hrs,}$ strips $1 \mathrm{~cm}$. wide were scraped off the plate and eluted with distilled water. The $\mathrm{pH}$ in the eluate was measured, using a Radiometer, type 26 . The proteins in the fractions were concentrated by precipitating in the cold with 
$\left(\mathrm{NH}_{4}\right)_{2} \mathrm{SO}_{4}$ at 50 per cent. saturation and redissolved in distilled water. After dialysis in distilled water for $48 \mathrm{hrs}$ (25-fold excess, one change), the amount of protein was measured. These fractions were then studied for their effect on TT. IgG preparations from individual syphilitic patients, or fractions obtained after zone electrophoresis and isoelectrofocusing, were assayed for their activity in the TTT as follows:

$0.1 \mathrm{ml}$. of the solution was added to $0.5 \mathrm{ml}$. of pooled normal sera. The spectrophotometric readings of these mixtures in the TTT were compared with that found for a blank consisting of $0.5 \mathrm{ml}$. of the same serum pool and $0 \cdot 1 \mathrm{ml}$. of saline.

For the above-mentioned fractions, extinction units per mg. protein $(\Delta E)$ were calculated from the increase in extinction and the final concentration of added protein, according to the formula

$$
\Delta E=\frac{6 . \Delta E \text { measured }}{\text { protein concentration of fraction }}
$$

\section{Results}

The zone electrophoresis experiments on Pevikon blocks show that the most basic fractions of the gamma region are most active in enhancing the thymol turbidity. The results of a typical experiment are given in the Table. The twelve sera separated in this way all show similar patterns. In all cases the basic fractions exert the strongest effect on the thymol turbidity as expressed in extinction units per mg. of protein.

Double diffusion experiments with the concentrated fractions of the gamma region indicate that the two most basic fractions, and very often also the third, contain only IgG. In less basic fractions the next protein detected is an IgM.

Fig. 1 shows the results of one of the isoelectrofocusing experiments. It is apparent that not all of the IgG fractions exert an effect in the TTT, since fractions isolated below $\mathrm{pH}=\mathbf{7 . 6}$ are totally inactive. The addition of the latter to serum gave extinction readings similar to that found for the blank. Only IgG fractions isolated at $\mathrm{pH}>7.6$ are able to increase the TT. The higher the isoelectric point of the fraction, the higher the activity in the TTT.

Fig. 2 shows the effect on the TT of fractions obtained by isoelectrofocusing of different IgG preparations. In all seven preparations used the enhancing effect on the TTT starts around $\mathrm{pH}=7.6$ and increases as the isoelectric point of the isolated fraction increases.

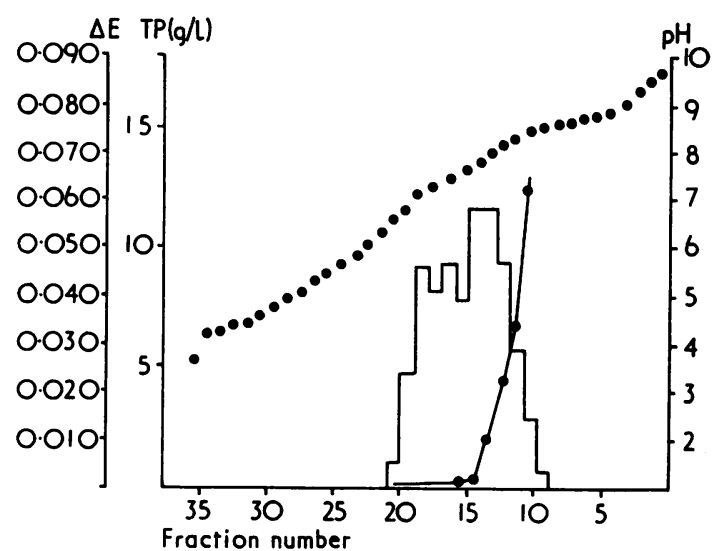

FIG. 1 Effect on TT of IgG fractions isolated by isoelectrofocusing

Abcissa: fraction number

Ordinates: right hand: $p H(.$.

left hand: Increase in $T T(\Delta E)$, expressed as extinction units per $\mathrm{mg}$. protein of fractions $(\cdot-\cdot)$

Total protein (TP) content (g./l.) of isolated fractions (columns)

Fig. 3 shows the increase in TT (expressed as extinction units) which is caused by the addition of IgG preparations from individual patients to normal serum. It can be seen that all four preparations are able to increase the thymol turbidity. The strongest effect is exerted by IgG from a syphilis patient in the secondary stage of the disease.

\section{Discussion}

From the zone electrophoresis experiments it is obvious that IgG plays a role in the TTT. It is possible that in the most basic fractions some IgM is present at a concentration less than $0.03 \mathrm{~g} . / 1$. (lowest detection level of the double diffusion method). The concentration of IgM, if present, in the basic fractions obtained by zone electrophoresis, is far less than the $1 \mathrm{~g}$./1. used by Hartmann and others (1963). However, the starter mechanism cannot be excluded because of the presence of IgM in the serum to which the fractions were added.

With respect to the micro-heterogeneity of the

T A B L E Effect of fractions of the gamma region of the serum from a syphilitic patient, isolated by Pevikon electrophoresis. Fractions numbered from cathodal end of block

\begin{tabular}{|c|c|c|c|c|c|}
\hline $\begin{array}{l}\text { Fraction } \\
\text { number }\end{array}$ & $\begin{array}{l}\text { Protein } \\
\text { content } \\
\text { (mg./ml.) }\end{array}$ & $\Delta E$ & $\begin{array}{l}\text { Fraction } \\
\text { number }\end{array}$ & $\begin{array}{l}\text { Protein } \\
\text { content } \\
\text { (mg./ml.) }\end{array}$ & $\Delta E$ \\
\hline $\begin{array}{l}1 \\
2 \\
3 \\
4\end{array}$ & $\begin{array}{r}2 \cdot 1 \\
8 \cdot 0 \\
12 \cdot 8 \\
22 \cdot 7\end{array}$ & $\begin{array}{l}0.029 \\
0.006 \\
0.008 \\
0.007\end{array}$ & $\begin{array}{l}5 \\
6 \\
7 \\
8\end{array}$ & $\begin{array}{l}19 \cdot 8 \\
18 \cdot 2 \\
18 \cdot 1 \\
12 \cdot 2\end{array}$ & $\begin{array}{l}0.007 \\
0.005 \\
0.005 \\
0.004\end{array}$ \\
\hline
\end{tabular}




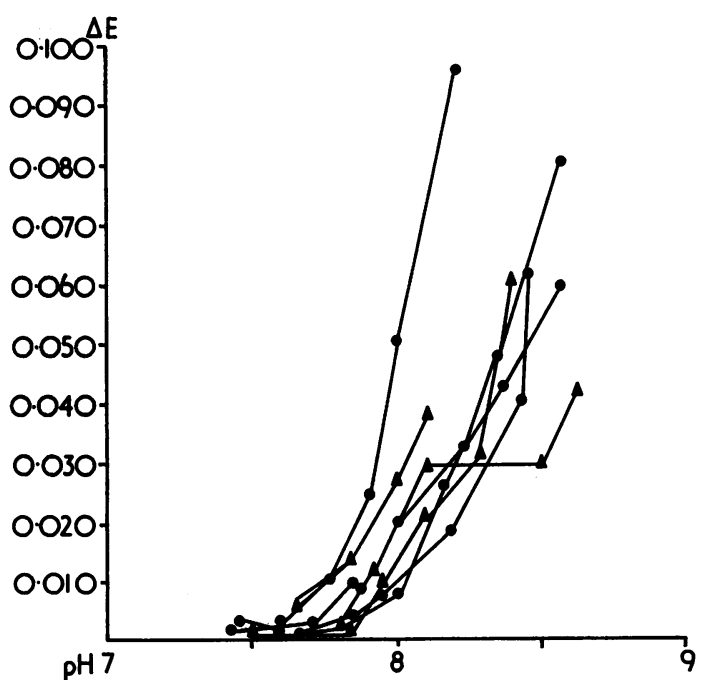

FIG. 2 Effect on $T T$ of $I g G$ fractions from seven different IgG preparations, separated by isoelectrofocusing

Abcissa: $\quad p H$

Ordinate: Increase in $T T(\Delta E)$, expressed as extinction units per $\mathrm{mg}$. protein

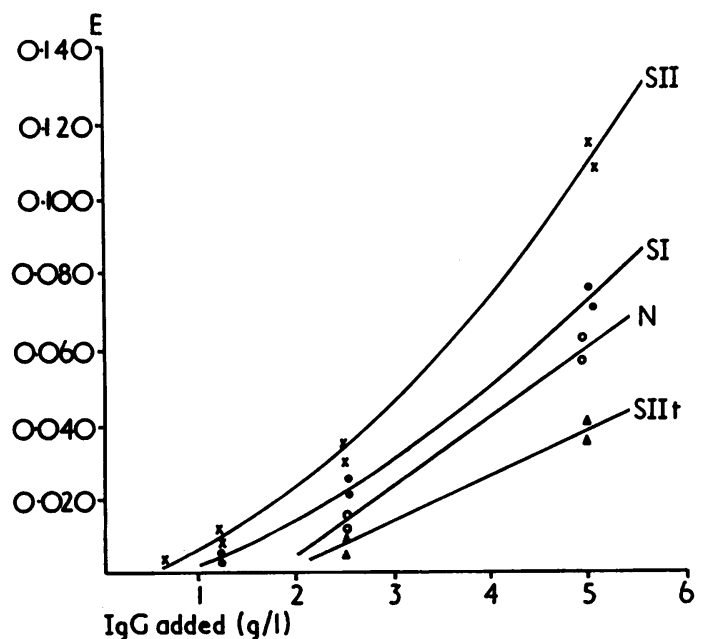

FIG. 3 Extinction increase $(E)$ in TTT by IgG isolated from normal sera and from sera of syphilitic patients at different stages of disease.

$N=$ normal $I g G$,

$S I I=I g G$ of patient in secondary stage,

$S I=I g G$ from patient in seropositive primary stage,

SIIt $=I g G$ from patient in secondary stage after 6 weeks' penicillin treatment

immunoglobulins, the zone electrophoresis experiments give little information about the mechanism of the enhancing effect of $\mathrm{IgG}$.

In this regard the isoelectrofocusing experiments provide pertinent data. Only IgG fractions with isoelectric points above 7.6 take part in the TT. This $\mathrm{pH}$ value coincides with the $\mathrm{pH}$ of the thymol reagent. Obviously, only IgG molecules which carry a positive charge at this $\mathrm{pH}$ would contribute to the TT.

Moreover, the effect seems to depend on the whole IgG molecule, since we found that degradation of an active IgG preparation to $3.5 \mathrm{~S}$ units by papain (van Eyk, 1966) causes the loss of the ability to enhance the TT. Isoelectrofocusing of this $3.5 \mathrm{~S}$ preparation revealed that protein was present in fractions isolated at a $\mathrm{pH}$ above $7 \cdot 6$. The increase in TT in syphilis sera suggests that during an infection with $T$. pallidum production of antibodies with high isoelectric points is stimulated. Evidence for this is found in Fig. 3, where it is seen that IgG from untreated syphilitic patients has a stronger effect on the TT than normal IgG. It seems, therefore, that in syphilitic sera the amount of basic immunoglobulins of the IgG class is raised. Whether this increase reflects some kind of specificity of the immune response to infection with $T$. pallidum or is the result of a hypergammaglobulinaemia remains to be studied. The results in Fig. 3 favour the former hypothesis to some extent. Additional work on this subject is presented in the following paper.

\section{Summary}

It is demonstrated that IgG fractions with isoelectric points above $7 \cdot 6$, isolated from pooled syphilitic sera, are able to elevate the thymol turbidity. The effect increases with increasing isoelectric points of the isolated fraction.

IgG from individual syphilitic patients exerts a stronger effect on the thymol turbidity than normal IgG. It is concluded that elevated amounts of these basic immunoglobulins are present in the sera of syphilitic subjects.

\section{References}

BoccI, V. (1964) Arch. Biochem. Biophys., 104, 514

EYK, H. G. vAN (1966) Biochim. biophys. Acta, 127, 241

Franklin, E. C. (1959) Clin. chim. Acta, 4, 259

Hartmann, L., Viallet, A., and Fauvert, R. (1963) Ibid., 8, 872

Kunkel, H. G., and Hoagland, C. L. (1947) f. clin. Invest., 26, 1060

MENKE, H. E. (1975) Thesis, Erasmus University, Rotterdam

Ouchterlony, O. (1958) Progr. Allergy, 5, 1

RADOLA, B. J. (1969) Biochim. biophys. Acta, 194, 335

Reinhold, J. G. (1960) Advanc. clin. Chem., 3, 83

ScheIDEgGER, J. J. (1955) Int. Arch. Allergy, 7, 103

STRFFEN, C. (1968) 'Allgemeine und experimentelle Immunologie und Immunpathologie', p. 563. Thieme, Stuttgart

STILLERMAN, H. B. (1948) F. Lab. clin. Med., 33, 565

Wriss, C. (1969) 'Diagnostische Bewertung von Laborbefunden', p. 356. Lehmans, München 